\title{
Accessing Middle School Social Studies Content Through Universal Design for Learning
}

\author{
Megan Mackey \\ Central Connecticut State University
}

\begin{abstract}
Universal design for learning is intended to provide opportunities for all students to be successful. An exploration of Mr. Morales's middle school social studies classroom reveals the universal design for learning principles of multiple means of engagement, representation, and action and expression infused throughout every lesson. These strategies afford access to knowledge and skill development for all students.
\end{abstract}

Keywords: universal design for learning, social studies, accessing content

\section{Introduction}

Individuals bring vast and varied experiences, interests, skills, and needs into classrooms. Universal design for learning (UDL) is a framework designed to provide all students, including students with disabilities and culturally and linguistically diverse learners, with access and opportunity to learn the curriculum (Chita-Tegmark, Gravel, Serpa, Domings, \& Rose, 2012; Rao, 2015). "UDL provides a blueprint for creating instructional goals, methods, materials, and assessments that work for everyone" (National Center on UDL, 2017).

UDL principles emphasize providing options geared toward meeting the needs of all learners by incorporating flexibility into lessons (Rose \& Gravel, 2009). Providing flexibility allows for maximum stimulation of the affective networks (the "why" of learning), the recognition networks (the "what" of learning), and the strategic networks (the "how" of learning; Meyer, Rose, \& Gordon 2014; National Center on UDL, 2017; Novak, 2016), depicted in Figure 1.

UDL aims to actively involve and engage all learners, consider all three learning networks when planning instruction, and separate the means of understanding something from the end (Meyer et al., 2014). To accomplish this and "provide equitable opportunities to reach high standards across variable students in our schools, (teachers) must: provide multiple means of engagement, provide multiple means of representation, and provide multiple means of action and expression" (Figure 2; CAST, 2018).

UDL is most effective when it is applied to all aspects of the learning process. This includes the values with underlie the class climate, the types of interactions between and amongst teachers and students, the classroom setup and physical space, the instructional strategies utilized, the resources available, the feedback provided, and the frequency and type of evaluation. (The Center for Universal Design in Education, 2012). UDL requires intentional planning to be effective. Teachers need to consider learner variability when it comes to planning their instruction and assessment (Lowrey, Hollingshead, Howery, \& Bishop, 2017). UDL provides teacher with a method to reflect on all aspects of their planning and teaching to identify where obstacles exist for students. UDL also provides a framework whereby teachers can remove or minimize those obstacles (Rao \& Torres, 2017). This intentional planning is evident in Mr. Morales's classroom. 


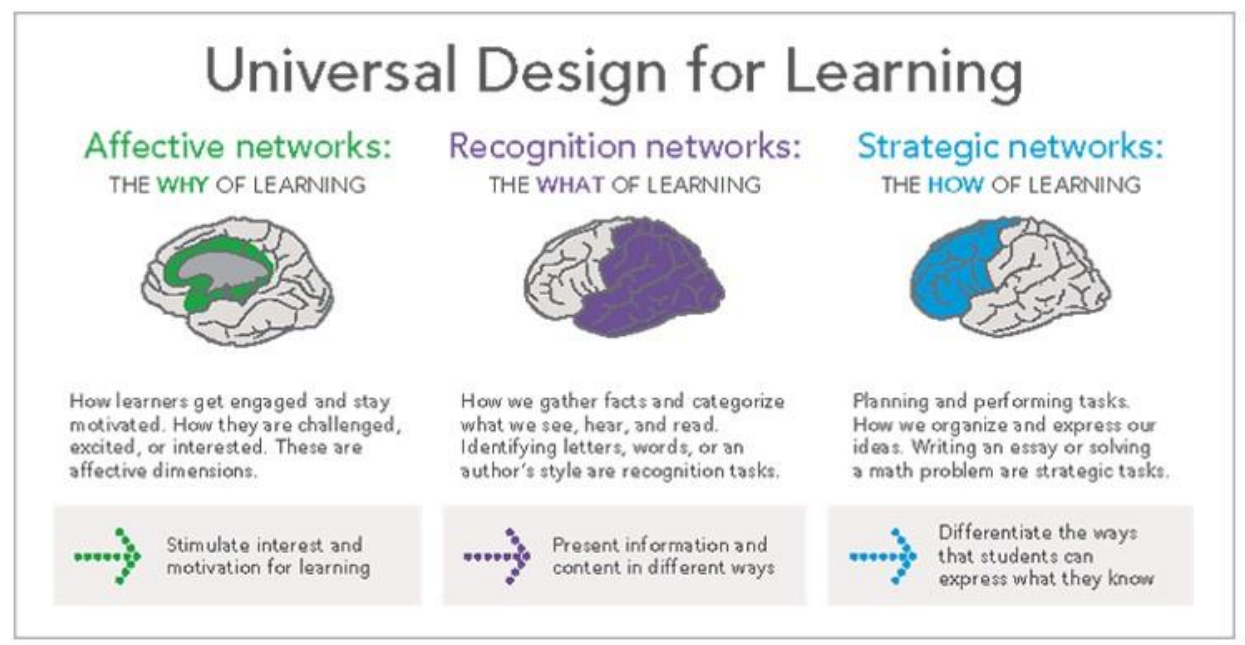

Figure 1. Universal Design for Learning (UDL, 2015)
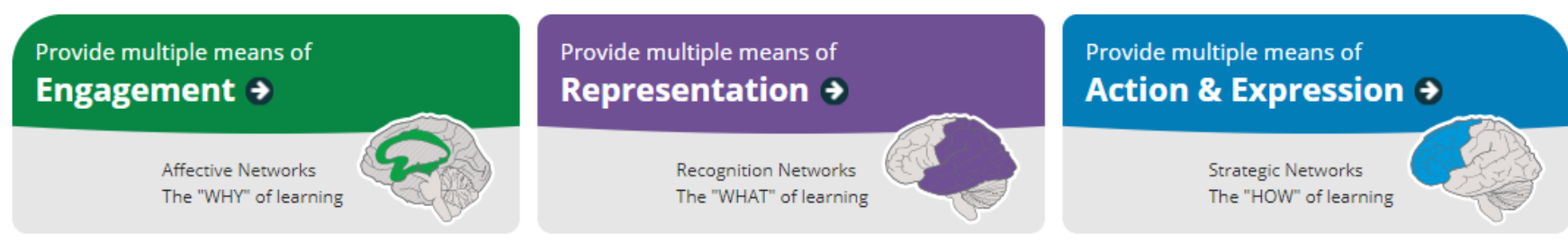

Figure 2. Learning Networks (CAST, 2018)

\section{Mr. Morales}

Mr. Morales is in his sixth year of teaching at a middle school in the southwest United States where over $65 \%$ of the student population qualifies for free and reduced lunch (compared to $34 \%$ in the district and $51 \%$ in the county). The student body consists of $63 \%$ White (non-Hispanic) and $36 \%$ Hispanic students. Over 58\% of the students qualify for either an English Language Learner (ELL) Plan, created for students whose home language was something other than English and who struggled academically as a result; an Individual Literacy Plan, which is developed for students who did not have a diagnosed disability but who struggle with reading; or an Individualized Education Program, created for students identified as having a disability. This means that in each of Mr. Morales's classes, over half of the students have a significant academic need.

Mr. Morales took only one course in his undergraduate teacher preparation program that addressed the needs of diverse learners and that course focused on getting teachers to empathize with families as opposed to learning strategies to meet student needs. He earned his master's degree in English as a second language and acted as the school's English-as-a-second-language coordinator. Mr. Morales did not have any formal education on the components of UDL principles and practices in his undergraduate or graduate programs. Instead, he had an insatiable desire to improve his teaching and explored effective strategies on his own.

This "self-taught" educator infused UDL elements throughout his classroom learning environment through high levels of engagement, daily success for all students, and address the needs of all 
learners, including students with disabilities, ELLs, at-risk learners, and students from diverse backgrounds. These practices improve the knowledge and educational outcomes of diverse populations and benefit historically marginalized groups.

\section{UDL Guideline: Engagement}

As Brand, Favazza, and Dalton (2012) noted, "Educators make learning personally relevant as they integrate students' lives into lessons that are socially relevant and appropriate to students' developmental stages and abilities, diverse backgrounds, and prior knowledge" (p. 135). Mr. Morales recruits students' interest by having them complete a map at the beginning of each unit to situate themselves in relation to the content.

Another key component of engagement is sustaining effort and persistence by varying levels of challenge and support and fostering collaboration (Brand et al., 2012). This is evident in Mr. Morales's use of a round table to provide guidance and feedback and allow for collaboration. He also clearly communicates his goals and expectations for the activity. In doing so, the teacher optimizes authenticity and personal connection, and minimizes threats and distractions (National Center on UDL, 2017).

\section{Engagement Vignette}

Mr. Morales handed out an assignment and asked a student to read the title of instructional guide, The Impact of Colonization (Lumen Learning, 2017). Mr. Morales provided students with a blank map of North America. He had eliminated extraneous rivers and sectioned the map off into regions with dark, heavy lines to make labeling easier for students. Mr. Morales had students complete some type of map at the beginning of a unit to help them better understand the information. He felt it helped students visualize the area and situate themselves in a certain time period.

Mr. Morales read through the instructional guide and explained to students his expectations for each of the eleven directives. He showed students models and examples of the completed assignments and asked if there were any questions. He usually showed students examples of the completed assignments to give them a clear idea of what he expected of them.

Mr. Morales informed students that, as always, they could come to the "round table" to get assistance. The round table was actually two trapezoid-shaped tables in the back right corner of the classroom pushed together to form a hexagon. In previous years, Mr. Morales had sat at his desk during work time. He felt that students did not find him as approachable and sometimes it prevented them from seeking help. Mr. Morales found that by situating himself in a more welcoming situation, students approached him more frequently and expressed being more comfortable asking for help. In turn, Mr. Morales discovered that students were more engaged in lessons and tasks for longer periods of time.

Mr. Morales read the first directive to the students at the round table and reminded them to label the bodies of water and to neatly color each of them. Mr. Morales remained seated for a few minutes and monitored the students as they worked. He then got up, walked around the classroom, and checked on the progress of the other students. While walking around the classroom, Mr. Morales noticed that a student seated at his own desk had fallen behind in his work. He asked the student to move to the round table to receive some support. The student picked up his materials and moved to the round table. Mr. Morales followed and sat down next to him at the round table. Mr. Morales spent a few minutes helping the student get caught up with the other students. 


\section{UDL Guideline: Representation}

To address students' diverse needs, teachers present and represent information and evaluations in a wide range of formats (Brand et al., 2012). Mr. Morales skillfully provided students access to multiple materials through the use of preselected texts and technology. He offered multisensory approaches to learning by incorporating the writing of an essay and the creation of a ceramic representation. Mr. Morales guided information processing and the development of comprehension through scaffolded instruction. Finally, he offered ways for students to customize their presentation of information. These strategies embody the UDL guideline of representation (National Center on UDL, 2017).

\section{Representation Vignette}

Toward the end of a Native American unit, Mr. Morales took his class to the library for 2.5 days to conduct research on a tribe of their choosing. Students used preselected books, encyclopedias, and the Internet to locate information that pertained to the daily life, jobs, roles of men and women, food supply, homes, leisure, education, traditions, religious practices, and rituals of their chosen tribe. Students then spent 2 days in the computer lab writing and typing their essay. Mr. Morales reviewed the specific expectations for each of the four paragraphs of the essay at the beginning of each class and also posted the expectations on the whiteboard. When students finished their writing, Mr. Morales paired them up with a classmate to peer edit the essay. Students who finished early played a Native American trivia game posted on Mr. Morales's website. The few students who did not finish typing their essay during the time in the computer lab were expected to finish it as homework.

For the second part of the project, students painted one of a four ceramic Native American pieces. On the day students began to paint, Mr. Morales pulled up a PowerPoint slide on the LCD projector that contained a breakdown of the grading for the tribal history art project. Mr. Morales prepared all of the materials in advance, so once students selected their piece, they immediately began to paint. He put on some soft instrumental music and sat down at his desk.

After students had completed both parts of the Native Americans project, Mr. Morales invited a few teachers to judge both the essays and the painted ceramic pieces. Based on teachers' votes, Mr. Morales rewarded the top 20 vote-getters with an arrowhead. He also put their projects on display in the main foyer, where they remained for a few weeks.

Following the tribal history art project, Mr. Morales introduced students to the book I Am Regina (Keehn, 2001). He informed students they would be reading it over the course of the next few weeks. The book was about a girl in Pennsylvania who was captured by the same Indians who killed her father and brother. She lived with the Indians for 8 years before she was reunited with her family. Mr. Morales used this book because it provided both the colonists' and the Indians' perspective on life in America.

On the second day of reading I Am Regina (Keehn, 2001), Mr. Morales presented the following assignment:

1. Analyze the song on p. 15. Rewrite each line in your own words. (Make it more understandable by rewriting it in our more modern/common language).

2. Why does the family find comfort and strength in these words? Explain.

Mr. Morales had students share their thoughts and interpretations about the book before he began the day's lesson. Once a number of students had shared their responses, Mr. Morales asked for volunteers to explain what they had read the day before. 


\section{UDL Guideline: Action and Expression}

Teachers provide students with options for demonstrating and expressing their understanding of a given skill or concept, while supporting and guiding them through the process (Brand et al., 2012). Mr. Morales provides each group with clear expectations and guidelines, but he allows for flexibility in the manner in which students navigate and respond to information. Mr. Morales uses a variety of tools for students to construct and demonstrate their understanding and supports planning and strategic development.

\section{Action and Expression Vignette}

During a unit that addressed the colonization of America, Mr. Morales explained to students that for the next day and a half, they would work together to problem-solve some of the economic, social, and geographic challenges that colonists faced when they settled in America. He pulled up a slide entitled, "Procedures for Group Work." Each of the procedures was written in green:

1. Everyone's voice matters,

2. Everyone participates, and

3. Discuss your challenge quietly with your group.

Further details listed under each procedure were written in blue and black. The "Consequences for Not Following Procedures" section was written in red and explained that students would work alone on two separate assessments if they did not work well within their group.

Mr. Morales then introduced the challenge:

Imagine yourself as a colonist. You've come over to the Americas. You've been on a 2-month journey. This classroom is our colony. Each group is going to address a problem we are having in our colony. You are going to talk about what the problem is, how you are going to address it, and what consequences the colonists face if they don't follow the rules. Tomorrow, we are going to have a town meeting and you will present the problems and the solutions. Any questions? So you guys are basically thinking, "What's it going to take to survive in the new world?" Everybody grab your challenges in front of you, work in your group, and start thinking about it. Have fun, enjoy the challenge, and learn together.

Mr. Morales handed out a different challenge to each mixed-ability group and students immediately got to work. Mr. Morales felt that having students work in groups helped them think more in depth and enhanced their understanding of content. He tried to create activities that forced students to think about multiple perspectives.

Halfway through the next day, Mr. Morales had each group present their challenge and solutions. Before they presented, he reminded the class that they were colonists and this was their town meeting. He told them, "As [groups] present, I want you to think about the problem they had to assess and their solution. Is their solution adequate enough? Will we truly survive or will our colony fail?" One group had to solve the "Geography Challenge" and determine what natural resources in the region would be beneficial, what tools would be needed to build a settlement, and where the settlement needed to be built. Each of the four group members presented a different section of the poster, and Mr. Morales posed questions. 
Mr. Morales: What's the design of your fort or settlement?

Student 1: Triangle.

Mr. Morales: Why?

Student 1: Less sides to protect.

Mr. Morales: What would you like to build it right next to?

Student 2: A river.

Mr. Morales: Why would you want to build it next to a river?

Student 2: For water.

Mr. Morales: Think about security and defense. For security and defense, where would it be good to build a fort or a settlement because it'd be easy to defend?

Student 3: Mountain.

Mr. Morales: Where on the mountain would be an ideal place for defense?

Student 3: On top.

Mr. Morales: Why would you want to be on top?

Student 3: Harder to attack.

Mr. Morales asked the class if they had any questions for their fellow colonists.

A few days later, Mr. Morales introduced students to the notion that not all settlers in America had come willingly. Afterward, his question of the day read, "Look at these two pictures. What can you infer about the conditions aboard the ships on which Africans were transported to the Americas?" Mr. Morales spent a few minutes having students share their inferences and then he explained,

What we are going to do today is watch a video and the video is called Roots (Chomsky, Erman, Greene, Moses, \& Margulies, 1977). The beginning is going to start in Africa. Kunta Kinte is living in this village with his family and he has just transferred into manhood and he is a warrior in his tribe. Today is his brother's birthday and he is going to make his brother a drum. When he is looking for a log he is taken captive and he is taken away. Watch closely because I'm going to pause and ask you questions.

Mr. Morales then played a 20-min clip that showed Kunta Kinte's capture and subsequent placement on a ship. It also showed his family's discovery of his capture. Mr. Morales stopped the video and said,

Imagine you were walking along, a van came up, snatched you, chained you, put you on a ship, and you were taken clear across the world and you were with people who didn't speak the same language. What are some feelings you would have and what would you do? Talk with your neighbor. How would you feel and what you would you do in this situation?

Mr. Morales tried to connect content to students' lives as much as possible. He provided students with time to discuss their thoughts with a classmate, and animated discussions filled the classroom. After a while, Mr. Morales had students share their thoughts, feelings, and solutions aloud. Mr. Morales asked students where on the ship slaves were kept, and students replied, "the hold." Mr. Morales explained that they would get to see what a hold was like in the next clip. At the end of the 10-min clip, Mr. Morales again posed a question, had students talk with a classmate, and then share their thoughts aloud. He repeated this process with a clip that showed Kunta Kinte being sold.

Mr. Morales stopped the video just before the bell rang and asked the class one last thing. "This video is laced with something that is apparent in our society. That is the idea that someone is better than someone else based on the color of their skin. What is that called?" A few students responded chorally, "Racism," as everyone picked up their materials and walked out of the classroom. 


\section{Conclusion}

Close examination of the vignettes will reveal that although labeled for a specific UDL guideline, multiple means of engagement, representation, and provide multiple means of action and expression permeate them all (UDL, 2015). By applying the principles of UDL to all areas of teaching and learning, Mr. Morales is maximizing his impact on the affective, recognition, and strategic networks (Meyer et al., 2014; National Center on UDL, 2017; Novak, 2016; The Center for Universal Design in Education, 2012). Mr. Morales established a learning environment with high levels of engagement and daily success for all students. UDL permeated his instructional strategies, which allowed him to address the needs of all learners, including students with disabilities, ELLs, at-risk learners, and students from diverse backgrounds. These practices clearly improve the knowledge and educational outcomes of diverse populations and benefit historically marginalized groups (Chita-Tegmark et al., 2012; Rao, 2015). These are exactly the equitable opportunities for which UDL was developed.

\section{References}

Brand, S. T., Favazza, A. E., \& Dalton, E. M. (2012). Universal design for learning: A blueprint for success for all learners. Kappa Delta Pi Record, 48, 134-139.

CAST. (2018). Universal design for learning guidelines, Version 2.2. Wakefield, MA: Author. Retrieved from http://udlguidelines.cast.org/

Chita-Tegmark, M., Gravel, J. W., Serpa, M. d. L. B., Domings, Y., \& Rose, D. H. (2012). Using the universal design for learning framework to support culturally diverse learners. Journal of Education, 192, 17-22.

Chomsky, M. J., Erman, J., Greene, D., \& Moses, G. (Directors), Margulies, S. (Producer). (1977). Roots. United States: Wolper Productions.

Keehn, S. M. (2001). I am Regina. New York, NY: Penguin.

Lowrey, K. A., Hollingshead, A., Howery, K., \& Bishop, J. B. (2017). More than one way: Stories of UDL and inclusive classrooms. Research and Practice for Persons With Severe Disabilities, $42,225-242$.

Lumen Learning. (2017). The impact of colonization. Retrieved from https://courses.lumenlearning.com/ushistory1os2xmaster/chapter/the-impact-of-colonization/

Meyer, A., Rose, D. H., \& Gordon, D. T. (2014). Universal design for learning: Theory and practice. Wakefield, MA: CAST Professional Publishing.

National Center on Universal Design for Learning (UDL). (2017). About UDL: Learn the basics. Retrieved from www.udlcenter.org

Novak, K. (2016). UDL now! A teacher's Monday morning guide to implementing the common core standards using universal design for learning. Wakefield, MA: CAST Professional Publishing.

Rao, K. (2015). Universal design for learning and multimedia technology: Supporting culturally and linguistically diverse students. Journal of Educational Multimedia and Hypermedia, 24, 121-137.

Rao, K., \& Torres, C. (2017). Supporting academic and affective learning processes for English language learners with universal design for learning. TESOL Quarterly, 51, 460-472.

Rose, D. H., \& Gravel, J. W. (2009). Getting from here to there: UDL, global positioning systems, and lessons for improving education. In D. T. Gordon, J. W. Gravel, \& L. A. Schifter (Eds.), A policy reader in universal design for learning (pp. 5-18). Cambridge, MA: Harvard Education Press. 
The Center for Universal Design in Education. (2012). Universal design in education: Principles and applications. Retrieved from www.washington.edu/doit

Universal Design for Learning (UDL). (2015). Collaboration for Effective Educator Development, Accountability and Reform (CEEDAR) Center. Retrieved from http://ceedar.education.ufl.edu/

The Journal of Educational Research and Practice provides a forum for studies and dialogue that allows readers to better develop social change in the field of education and learning. Journal content may focus on educational issues of all ages and in all settings. It also presents peer-reviewed commentaries, book reviews, interviews of prominent individuals, and additional content. The objectives: We publish research and related content that examines current relevant educational issues and processes aimed at presenting readers with knowledge and showing how that knowledge can be used to impact social change in educational or learning environments. Additional content provides an opportunity for scholarly and professional dialogue regarding that content's usefulness in expanding the body of scholarly knowledge and increasing readers' effectiveness as educators. The journal also focuses on facilitating the activities of both researcher-practitioners and practitioner-researchers, providing optimal opportunities for interdisciplinary and collaborative thought through blogging and other communications.

Walden University Publishing: http://www.publishing.waldenu.edu 